visa applications for foreign researchers and give international science and engineering students an automatic one-year visa extension to seek work or advanced study.

\section{Suspended urologist set to return to Austrian university}

The urologist at the centre of Austria's biggest-ever research scandal can return to work at the Medical University of Innsbruck, a disciplinary committee has ruled.

Hannes Strasser was suspended from clinical, teaching and research duties in September 2008 following accusations of malpractice in a clinical trial using stem cells to treat urinary incontinence (see Nature 454, 922; 2008).

The national disciplinary committee responsible for university staff has now concluded that the suspension was not legally justified, as more than three years had passed since the alleged misdemeanour occurred.

Strasser, who is facing criminal charges relating to harming patients or putting them at risk of harm, is on paid leave until the end of January. He will not be allowed to treat patients until the criminal case is resolved - which is likely to take at least a year. An investigation by the Austrian National Academy of Sciences is also ongoing.

\section{Coal conversion plant fires up in China}

China's first coal-liquefaction plant is up and running. Located in Inner Mongolia, the facility is run by the state-owned Shenhua Group.

According to a statement issued by Shenhua last week, the plant has been turning coal into liquid fuel and chemical products since December. The technique, which is also widely used in South Africa, has been criticized for its high emissions of carbon dioxide.

Last year, the Chinese government issued a moratorium on new coal-liquefaction facilities, but allowed Shenhua to complete its Mongolia plant and continue work on a second. The company says it is developing ways to capture and store the $\mathrm{CO}_{2}$ emitted during the process.

\section{Italian universities lose freedom to appoint staff}

Italian universities will have little say in choosing their own professors thanks to a law approved by parliament last week.

According to the new rules, a five-person selection committee will oversee each appointment. But a university recruiting a professor can appoint only one member to the board. The other four members will be picked at random from a list of twelve voted for by the relevant community of scientists across Italy.

The existing concorsi system is similar, but it allowed universities to have more control over selection - a privilege that was sometimes abused to make appointments based on local politics rather than on merit. Many academics had lobbied for a reform that would allow universities to make their own free choice, but lose funds if their chosen professors underperformed.

\section{Corrections}

The News round-up item 'Biodiversity gets catalogued online' (Nature 456, 844-845; 2008) gave incorrect funding numbers for the Encyclopedia of Life. The total budget for the project's first five years is US\$50 million; $\$ 2.5$ million came from the Sloan Foundation and $\$ 10$ million from the MacArthur Foundation in 2007

The News story 'Good grades, but who gets the cash?' (Nature 457, 13; 2009) incorrectly calculated the number of staff submitted by the University of Oxford who were rated world-leading and internationally excellent in the biological-sciences category of the 2008 Research Assessment Exercise. The correct number is 75 , putting the university in second place behind the University of Cambridge. 